\title{
POTENSI PEMANFAATAN DAUN SIRIH HUTAN DAN DAUN MIMBA UNTUK MENGENDALIKAN HAMA GUDANG KACANG TANAH DENGAN METODA BANTALAN KASA : LITERATURE REVIEW
}

\section{Potential Utilization of Forest Betal Leaves and Nemba Leaves to Control Pests in Peanut Warehouse with Method Bearing Method: Literature Review}

\author{
Taufik Hidayat, Puput Novita, Febri Yandi, Saripah Ulpah \\ Fakultas Pertanian Universitas IslamRiau \\ Jalan Kaharuddin NasutionNo 113 P. Marpoyan, Pekanbaru, Kode Pos 28284, Indonesia \\ E-mail: taufikhidayat22112017@gmail.com \\ [Diterima: Februari 2021; Disetujui: April 2021]
}

\begin{abstract}
Application of synthetic chemical insectices is known to be the most effective approach in addressing infestation of insect pests. However, conventional insecticides are not appropriate to be applied against pests of stored food materials, such as peanut due to the residue issue. Method of fumigation which negate the residue issue is also not feasible for public practice due to the hazard potency. This consideration necessitates the exploration of safe insecticide material such as neem leaf and piper leaf using suitable method. Paper presented here is a literature review design to analyze related to the important pest of stored peanut, content and effication of neem and piper leaves, and the efficiency of muslin-cloth pad containing the botanicals. Based on the neem characteristics which is anteefedant and the characteristics of piper leaf which is volatile. It can be concluded that botanicals from these two species prepared in muslin-cloth pad, would be able to control pest of stored peanut.
\end{abstract}

Keywords: Peanut Pest, Piper Leaf, Neem, Muslin-Cloth Pad

\begin{abstract}
ABSTRAK
Pengendalian hama secara kimiawi terbukti merupakan pendekatan yang efektif dalam mengatasi serangga hama. Akan tetapi, pemanfaatan insektisida konvensional tidak sesuai untuk dilakukan terhadap bahan simpan yang merupakan komoditas pangan seperti kacang tanah disebabkan pertimbangan residu yang dapat mencemari produk. Sedangkan fumigasi yang aman dari dampak residu juga tidak feasible untuk dilakukan oleh masyarkat karena potensi hazard dalam aplikasinya. Untuk itu perlu diteliti bahan yang aman dan juga efektif seperti daun mimba dan daun sirih hutan dengan cara yang praktis dan efisien. Penelitian ini menggunakan desain literature review dengan menganalisa artikel terkait hama gudang utama komoditas kacang tanah, kandungan, dan efikasi dari sirih hutan dan daun mimba, serta efisiensi metoda bantalan kasa untuk produk bahan simpan. Berdasarkan sifat daun mimba yang merupakan anteefedant dan daun sirih hutan yang memiliki bahan bersifat volatil, maka dapat disimpulkan penggunaan bantalan kasa dari kedua bahan tumbuhan ini efektif dan efisien dalam mengatasi hama kacang tanah pada penyimpanan.
\end{abstract}

Kata kunci: Hama Kacang Tanah, Sirih Hutan, Mimba, Bantalan Kasa

\section{PENDAHULUAN}

Kacang tanah merupakan salah satu satu komoditi yang sangat penting bagi warga negara Indonesia karena sering menjadi bagian dari kuliner masakan Indonesia. Tingginya kebutuhan masyarakat akan keperluan kacang tanah membuat komoditi ini selalu menjadi bagian dari barang yang selalu disediakan para pedagang keperluan harian mulai dari pedagang besar hingga ke pedagang kecil. Akan tetapi sebagaimana hasil pasca panen pertanian pada umumnya biji kacang tanah berpotensi mengalami kerusakan pada masa penyimpanan. 
Para pemilik usaha kecil menengah sering mengalami kerugian dalam penjualan kacang-kacangan. Hal tersebut diakibatkan oleh perkembangbiakan hama dalam penyimpanan yang begitu cepat, sehingga kacang-kacangan menjadi rusak dan tidak layak lagi untuk di perjual belikan. Salah satu hama yang sering menyerang pada penyimpanan kacang tanah adalah Tribolium castaneum Herbst atau biasa masyarakat umum menyebutnya kumbang tepung.

Untuk menekan perkembangan hama gudang pada pada penyimpanan kacang tanah perlu diupayakan bahan yang efektif dalam menekan kerusakan biji kacang tanah dan cara yang efesien dan praktis dalam mengatasi kerugian pada pemilik usaha kecil menenggah. Untuk itu digunakanlah insektisida nabati seperti daun sirih hutan dan daun mimba untuk menanggulangi hama gudang pada penyimpanan kacang tanah.

Insektisida nabati merupakan bahan aktif tunggal atau majemuk yang berasal dari tumbuhan yang bisa digunakan untuk mengendalikan organisme pengganggu. Insektisida nabati ini bisa berfungsi sebagai penolak, penarik, antifertilitas (pemandul), pembunuh, dan bentuk lainnya. Secara umum, insektisida nabati diartikan sebagai suatu insektisida yang bahan dasarnya dari tumbuhan yang relatif mudah dibuat dengan kemampuan dan teknologi terbatas (Arinda, 2017).

Tanaman sirih hutan adalah tanaman semak perdu yang biasanya dapat dijumpai di daerah hutan, terkadang juga ditanam di pekarangan dan ladang. Bahasa latin sirih hutan adalah Piper aduncum L. dalam bahasa Inggris tanaman sirih hutan mempunyai nama Amelaun Leaf (Anonimus, 2017).

Mimba, Azadirachta indica, dapat tumbuh dengan baik di daerah panas dan kering bahkan mampu tumbuh di daerah yang curah hujannya dibawah $500 \mathrm{~mm}$ per tahun, dan mimba merupakan bahan alam yang dapat dikembangkan sebagai insektisida nabati (Schmutterer, 1995).
Pemanfaatan dari pestisida nabati yang aman bagi manusia, tetap harus diupayakan sedemikian rupa sehingga aplikasinya dapat dilakukan secara praktis dan efisien, disamping efektif. Penggunaan bantalan kasa dapat merupakan pendekatan yang layak dipertimbangkan untuk melindungi bahan simpan, dalam hal ini kacang tanah, tanpa mengurangi kualitas tampilan dari bahan simpan tersebut.

\section{METODE PENELITIAN}

Paparan dalam artikel ini merupakan kajian literatur yang mendukung potensi pemanfaatan daun mimba dan sirih hutan yang diaplikasikan dalam bentuk bantalan kasa untuk mengendalikan serangan hama gudang kacang tanah. Untuk itu, berturut turut akan dirangkum dan disajikan informasi mengenai: Hama utama pada penyimpanan kacang tanah; Mimba dan potensinya sebagai bahan insektisida.

Sirih hutan dan potensinya sebagai bahan insektisida; Cara kerja pestisida nabati. Berdasarkan uraian yang dipaparkan, selanjutnya dibahas potensi pemanfaatan mimba dan sirih hutan yang diaplikasikan dengan menggunakan bantalan kasa.

Data yang digunakan dalam Narrative Reviev ini berasal dari penelusuran jurnal hasil penelitian yang sudah pernah dilakukan sebelum nya oleh para peneliti baik itu nasional ataupun internasional. Pada Google Scholar, Research Gate, PubMed mengunakan kata kunci yang dipilih yakni : Daun Mimba, Daun Sirih Hutan. Artikel yang digunakan dalan penulisan Narrative Reviev ini diakses mulai bulan september dengan tahun publikasi 20102020 yang diakses dengan fulltext dalam bentuk format pdf dan scholarly (peer reviewed journals). Kriteria jurnal yang digunakan dalam Narrative Reviev adalah penelitian berbahasa indonesia dan inggris.

Peneliti dalam melakukan penelitian ini melakukan pencarian artikel penelitian yang dipublikasikan secara online menggunakan search engine dengan kata kunci yang digunakan adalah sebagai berikut: 
Tabel 1. Data Base dan Keyword.

\begin{tabular}{l|l}
\hline Data base & Strategi pencarian artikel \\
\hline Google Scholar & Neem leaves Insecticides AND Piper Aduncum Insecticides \\
\cline { 2 - 2 } & Insektisida Daun Mimba AND Insektisida Daun Sirih hutan \\
\hline \multirow{3}{*}{ Research Gate } & Neem leaves Insecticides AND Piper Aduncum Insecticides \\
\hline \multirow{2}{*}{ PubMed } & Insektisida Daun Mimba AND Insektisida Daun Sirih hutan \\
\hline & Neem leaves Insecticides AND Piper Aduncum Insecticides \\
\hline
\end{tabular}

Jurnal yang di reveiw sesuai dengan kriteria penulisan dan terdapat tema hubungan pengunaan daun mimba dan daun sirih hutan sebagai insektisida serta pengaruhnya terhadap perkembangan hama gudang dan hama tanaman. Adapun Kriteria inklusi dam ekslusi adalah sebagai berikut:

a. Kriteria inklusi

b. Rentang waktu penerbitan jurnal maksimal 10 tahun terakhir 2010-2020

c. Bahasa yang digunakan adalah Bahasa Indonesia dan Bahasa Inggris

d. Artikel original, tidak berbentuk arbstrak ataupun potongan-potongan jurnal tetapi dalam bentuk full text

e. Artikel berisi tentang penelitian yang bertujuan untuk mengevaluasi dan mengeluarkan potensi daun mimba dan daun sirih hutan sebagai pestisida nabati f. Kriteria ekslusi

g. Jurnal yang di tampilkan tidak fulltext

h. Tahun terbit jurnal dibawah tahun yang telah di tetapkan

\section{HASIL}

Hasil dari penelusuran jurnal penelitian mengunakan database yang telah di tentukan, dengan memasukan keyword yang telah di tetapkan. Setelah mengekslusi jurnal penelitian yang tidak sesuai dengan tujuan penelitian, maka didapatkan 3 jurnal yang relavan dan berkaitan dengan topik sehingga dapat dilanjutkan menjadi bahan literature review.

Jurnal penelitian yang telah di review oleh peneliti akan dijabarkan dengan ringkas pada tabel berikut ini:

Tabel 2. Matriks Penyajian Data.

\begin{tabular}{|c|c|c|c|c|c|}
\hline $\begin{array}{l}\text { Judul penelitian, } \\
\text { penulis dan tahun } \\
\text { Penulisan }\end{array}$ & $\begin{array}{c}\text { Tujuan } \\
\text { penelitian }\end{array}$ & $\begin{array}{c}\text { Metode } \\
\text { penelitian dan } \\
\text { sampel }\end{array}$ & $\begin{array}{l}\text { Hasil atau } \\
\text { Temuan }\end{array}$ & Kesamaan & Perbedaan \\
\hline $\begin{array}{l}\text { Peran daun mimba } \\
\text { sebagai bahan } \\
\text { adiftif } \\
\text { vermikompos } \\
\text { terhadap intensitas } \\
\text { serangan hama } \\
\text { ulat Plutella } \\
\text { xylostella dan } \\
\text { hasil tanaman } \\
\text { kubis krop } \\
\text { (Brasicca } \\
\text { oleraceae var. } \\
\text { Capitata L.) } \\
\text { Penulis: Cicik } \\
\text { Fitriyatun } \\
\text { Nadhiroh, Mahayu } \\
\text { Moro Lestari, } \\
\text { Nurhidayati } \\
\text { (2018) }\end{array}$ & $\begin{array}{l}\text { Mengetahui } \\
\text { pengaruh } \\
\text { aplikasi } \\
\text { vermikompos } \\
\text { yang berbahan } \\
\text { aditif daun } \\
\text { mimba pada } \\
\text { tanaman kubis } \\
\text { terhadap hama } \\
\text { ulat Plutella } \\
\text { xylostella }\end{array}$ & $\begin{array}{l}\text { Penelitian ini } \\
\text { menggunakan } \\
\text { Rancangan Acak } \\
\text { Kelompok } \\
\text { (RAK) dengan } \\
\text { sampel } 3 \\
\text { tanaman }\end{array}$ & $\begin{array}{l}\text { Hasil perlakuan } \\
\text { campuran daun } \\
\text { mimba+ daun } \\
\text { pepaya dengan } \\
\text { dosis } 100 \\
\text { g/polybag } \\
\text { memberikan } \\
\text { hasil daun } \\
\text { tanaman yang } \\
\text { Tertinggi }\end{array}$ & $\begin{array}{l}\text { Menggunakan } \\
\text { petisida nabati } \\
\text { berasal dari daun } \\
\text { mimba yang } \\
\text { sudah } \\
\text { dikeringkan. }\end{array}$ & $\begin{array}{l}\text { Metode yang } \\
\text { digunakan } \\
\text { mengunakan } \\
\text { RAK }\end{array}$ \\
\hline $\begin{array}{l}\text { Pengaruh } \\
\text { Beberapa Dosis } \\
\text { Tepung Daun Sirih }\end{array}$ & $\begin{array}{l}\text { Mengetahui } \\
\text { dosis tepung } \\
\text { daun sirih hutan }\end{array}$ & $\begin{array}{l}\text { Penelitian ini } \\
\text { mengunakan } \\
\text { metode }\end{array}$ & $\begin{array}{l}\text { Hasil perlakuan } \\
\text { daun sirih hutan } \\
\text { dengan dosis }\end{array}$ & $\begin{array}{l}\text { Mengunakan } \\
\text { bahan yang sama } \\
\text { yaitu sirih hutan }\end{array}$ & $\begin{array}{l}\text { Sampel yang } \\
\text { digunakan hama } \\
\text { kumbang beras }\end{array}$ \\
\hline
\end{tabular}




\begin{tabular}{|c|c|c|c|c|c|}
\hline $\begin{array}{c}\text { Judul penelitian, } \\
\text { penulis dan tahun } \\
\text { Penulisan }\end{array}$ & $\begin{array}{c}\text { Tujuan } \\
\text { penelitian }\end{array}$ & $\begin{array}{c}\text { Metode } \\
\text { penelitian dan } \\
\text { sampel } \\
\end{array}$ & $\begin{array}{l}\text { Hasil atau } \\
\text { Temuan }\end{array}$ & Kesamaan & Perbedaan \\
\hline $\begin{array}{l}\text { Hutan (Piper } \\
\text { aduncum L.) } \\
\text { terhadap Hama } \\
\text { Kumbang Beras } \\
\text { (Sitophilus oryzae } \\
\text { L.) } \\
\text { Penulis } \\
\text { :RusliRustam, } \\
\text { Agus Sutikno, } \\
\text { Derry Harpian } \\
\text { Pratama } \\
\text { Putra }\end{array}$ & $\begin{array}{l}\text { (Piper aduncum } \\
\text { L.) sebagai } \\
\text { insektisida pada } \\
\text { hama kumbang } \\
\text { beras (Sitophilus } \\
\text { oryzae L.) }\end{array}$ & $\begin{array}{l}\text { Rancangan Acak } \\
\text { Lengkap (RAL) } \\
\text { Dengan sampel } \\
\text { kumbang beras } \\
\text { (Sitophilus } \\
\text { oryzae L.) }\end{array}$ & $\begin{array}{l}\text { 6/100g beras } \\
\text { dosis yang } \\
\text { efektif }\end{array}$ & $\begin{array}{l}\text { dan sama- sama } \\
\text { mengunakan } \\
\text { Rancangan Acak } \\
\text { Lengkap } \\
\text { (RAL) }\end{array}$ & \\
\hline $\begin{array}{l}\text { Assessment Of } \\
\text { The Insecticidal } \\
\text { Potency Of Neem } \\
\text { (Azadirachta } \\
\text { indica) Seed } \\
\text { Kernel Methanolic } \\
\text { And Aqueous } \\
\text { Extracts On The } \\
\text { Malaria Vector } \\
\text { Anopheles } \\
\text { gambiae } \\
\text { Penulis : Njom, } \\
\text { Victor Stephen, } \\
\text { Umeh, Ethel Doris } \\
\text { N. And Eze, } \\
\text { Chukwuma Simon } \\
\text { (2011) }\end{array}$ & $\begin{array}{l}\text { Untuk } \\
\text { Mengetahui } \\
\text { Potensi ekstrak } \\
\text { air dan metanol } \\
\text { biji mimba } \\
\text { (Azadirachta } \\
\text { indica A. Juss) } \\
\text { dalam } \\
\text { menghambat dan } \\
\text { mengganggu } \\
\text { perkembangan } \\
\text { nyamuk } \\
\text { Anopheles } \\
\text { dievaluasi di } \\
\text { laboratorium. }\end{array}$ & $\begin{array}{l}\text { Penelitian ini } \\
\text { mengunakan } \\
\text { metode } \\
\text { Rancangan Acak } \\
\text { Lengkap Sampel } \\
\text { yang digunakan } \\
\text { dalam penelitian } \\
\text { ini adalah } \\
\text { nyamuk } \\
\text { Anopheles }\end{array}$ & $\begin{array}{l}\text { potensi ekstrak } \\
\text { air dan metanol } \\
\text { biji mimba } \\
\text { dalam } \\
\text { pengendalia n } \\
\text { Anopheles } \\
\text { gambiae. } \\
\text { Paparan nyamuk } \\
\text { terhadap kedua } \\
\text { ekstrak Mimba } \\
\text { menyebabk an } \\
\text { kematian larva } \\
\text { Anophelesg } \\
\text { ambiae instar III } \\
\text { dan juga } \\
\text { memperpanj ang } \\
\text { masa } \\
\text { kepompong } \\
\text { (dalam hari) }\end{array}$ & $\begin{array}{l}\text { Terdapat } \\
\text { Kesamaan } \\
\text { Bahan }\end{array}$ & $\begin{array}{l}\text { Terdapat } \\
\text { perbedaan pada } \\
\text { objek penelitian } \\
\text { dan jenis bahan } \\
\text { yang digunakan. }\end{array}$ \\
\hline
\end{tabular}

\section{PEMBAHASAN}

\section{Hama Utama pada Penyimpanan Kacang Tanah}

Sebagaimana yang dilaporkan oleh Marwoto (2015), terdapat dua spesies hama yang didapati menyerang biji kacang tanah yaitu Kumbang bubuk Tribolium castaneum Herbst (Coleoptera : Tenebrionidae) dan ulat biji Corcyra cephalonica Stainton (Lepidoptera: Galleridae). Namun yang pertama lebih umum dijumpai.

Kumbang bubuk merupakan hama kosmopolitan yang ditemukan menyerang bahan simpan dari berbagai jenis komoditas. Meskipun sering dianggap merupakan hama sekunder yang biasanya merusak bahan yang kondisinya sudah rusak yang sebelumnya telah diserang oleh hama primer lainnya, namun pada komoditas tertentu hama ini ternyata dapat menyerang bahan simpan dalam kondisi utuh seperti yang dilaporkan oleh Pires et al.(2017) 32 di Brazil yang menyerang kacang almond utuh sehingga dikategorikan sebagai hama primer.

Bioekologi dari hama kumbang bubuk ini adalah sebagai berikut. Kumbang agak pipih, memanjang berwarna coklat, berukuran 3-4 mm, lama hidup kumbang 18 bulan. Telur diletakkan secara tunggal. Seekor kumbang betina mampu bertelur 46 butir sepanjang hidupnya. Larva yang baru menetas berbentuk lonjong berwarna putih keco-klatan dan makan biji. Larva berambut halus. Kepompong diletakkan di antara biji yang dimakan. Lama periode telur sampai menjadi kumbang 20 hari pada suhu $35 \mathrm{C}$ dan kelembaban $79 \%$ tetapi dapat menjadi 141 hari pada suhu $25 \mathrm{C}$ dan kelembaban $70 \%$. Gejala serangan ditunjukkan dengan larva dan kumbang makan biji kacang tanah sehingga menjadi berlubang, apabila kerusakan berat yang tersisa tinggal kulitnya saja. Sebagaimana pengendalian hama gudang 
pada umumnya, maka tindakan yang biasa direkomendasikan yaitu mengupayakan biji bebas telur hama, menurunkan kadar air simpan hingga $11 \%$, memastikan gudang bebas hama,khusus ntuk benih dapat perlakuan benih dengan insektisida, dan melakukan fumigasi (Marwoto, 2015). Mimba dan potensinya sebagai bahan insektisida.

Tanaman mimba (Azadirachta indica), terutama dalam biji dan daunnya mengandung beberapa komponen dari produksi metabolit sekunder seperti azadirachtin, salanin, meliantriol, nimbin dan nimbidin yang diduga sangat bermanfaat, baik dalam bidang pertanian (pestisida dan pupuk), maupun farmasi (kosmetik dan obat-obatan), (Aradilla, 2009).

Active Ingredients Azadirachtin, Salannin, Melandriol, and other limonoids. Action Mechanism Mitotic inhibitor, damages the hormonal system, food poison, feeding deterrent, oviposition deterrent, and impairs metamorphosis and reproduction, mortality.

\section{Mode of Action:}

Laxmishre dan Singh

(2018) merangkum cara kerja dari mimba sebagaimana terlihat pada Gambar 1. Pada tingkat fisiologi, azadirachtin menghambat sintesa dan melepaskan hormon ganti kulit (ecdysteroids) dari kelenjar prothorak gland, menyebabkan terjadinya ekdisis pada serangga pradewasa. IPada imamgo betina, mekanisma yang sama akan menyebabkan terjadinya sterilitas. Azadirachtin, salannin, dan melandriol, menyebabkan gelombang anti peristaltik pada saluran pencernaan serangga yang menyebabkan sensasi seperti pemuntahan yang membuat serangga menolak untuk makan (feeding deterrent). Mimba juga membuat imago betina menolak untuk meletakkan telur dengan demikian pestisida botani ini bersifat sebagai oviposition deterrent. Azadirachtin dan senyawa limonoid lainnya yang terdapat pada mimba menghambat enzim ecdysone 20 monooxygenase, suatu enzim yang bertanggung jawabdalam mengkatalisa langkah akhir dari konversi ecdysone menjadi hormon yang aktif, 20 - hydroxyecdysone, yang mengendalikan proses metamorfosis serangga.

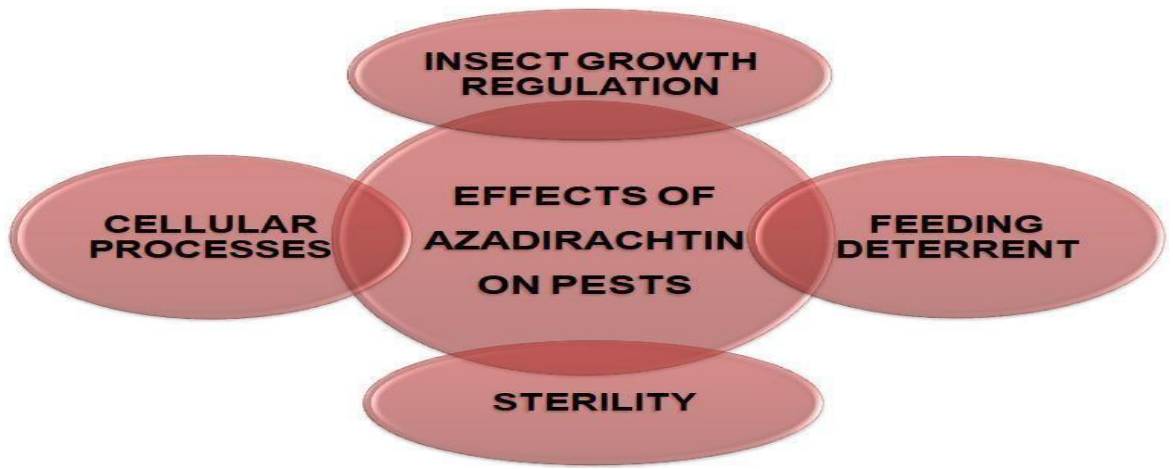

Gambar 1: Pengaruh Pestisida Berbasis Azadirachtin terhadap Serangga Hama (Laxmishree dan Singh, 2018).

\section{Sirih Hutan dan Potensinya sebagai Bahan Insektisida}

Kelompok tanaman sirih dari genus Piper diketahui menghasilkan sejumlah besar senyawa yang aktif secara fisiologi dan digunakan secara luas diberbagai belahan dunia sebagai bahan obatan. Famili Piperaceae terdiri dari lebih kurang 2000 spesies yang tersebar di daerah tropis di dunia. Piper aduncum L. dipergunakan secara uas dalam pengobatan tradisional untuk mengobati sakit perut, antiinflamasi dan antiseptik untuk menyembuhkan luka (Morandim et al. 2009). Penelitian lainnya melaporkan $P$. aduncum bersifat anti hipertensi, gastroprotective, hepatoprotective, anti-tumor, hypolipidemic, anti-inflammatory, antioxidant, anti- genotoxic, dan memiliki efek anti-cancerpada tikus (Arroyo-Acevedo et al. 2015).

Potensi sirih hutan sebagai insektisida dilaporkan (Aminah, 1995). Senyawa aktif yang terdapat pada tumbuhan Piperaceae termasuk dalam golongan piperamidin seperti piperin, piperisida, piperlonguminin dan guininsin. Senyawa tersebut telah banyak dilaporkan bersifat insektisida,daun sirih hutan 
juga mengandung senyawa- senyawa seperti heksana, sianida, saponin, tanin, flafonoid, steroid, alkanoid dan minyak atsiri yang diduga dapat berfungsi sebagai pestisida nabati. Rustam dkk (2017) melaporkan bahwa tepung daun sirih hutan efektif mengendalikan kumbang beras Sitophylus oryzae L.

\section{Cara Kerja Pestisida Nabati}

Pestisida nabati merupakan salah satu alternatif dari pestisida konvensional. Senyawa aktif dalam pestisida nabati merupakan senyawa metabolit sekunder yang terdapat pada tumbuhan yang tergolong aman bagi manusia. Sehingga berpotensi untuk memegang peranan penting dalam manajemen hama pertanian. Insektisida nabati mempengaruhi serangga dengan berbagai cara tergantung dari karakteristik spesies serangga dan juga tipe dari biomolekul dari tumbuhan tersebut. Cara kerja dari berbagai insektisida nabati dapat dikategorikan sebagai zat penolak (repellent), penolak makan (feeding deterrents/antifeedant), bersifat meracuni (toxicant), penghambat pertumbuhan dan perkembangan (growth retardant), pensteril (chemosterilant), dan zat penarik serangga (attractant) (Shivkumara, 2019).

Daun mimba juga bersifat sebagai fungisida, virusida, nematisida, bakterisida, dan akarisida. Mimba memiliki efek antiserangga. Ekstrak daunnya dapat menjadi fungisida alami untuk mengendalikan penyakit antraknosa pada apel setelah dipanen. Toksisitas dapat menyebabkan iritasi mata dan jaringan lunak, serta kemungkinan konjungtivitas dan inflamasi. Insektisida alami ini relatif aman bagi manusia, hewan, dan tanaman karena mudah terurai sehingga tidak menimbulkan residu. Daya meracunnya umumnya berupa repelen, menghambat peletakan telur, dan sebagai antifidan. Daun mimba mengandung komponen aktif yang menimbulkan bau dan aroma yang tidak disukai oleh hama kumbang bubuk sehingga bahan tersebut memiliki potensi sebagai insektisida (Saenong, 2016).

Insektisida nabati memiliki beberapa kelebihan yaitu tidak persisten pada lingkungan, memiliki resiko rendah atau bahkan tidak beresiko terhadap serangga menguntungkan lainnya seperti predator dan parasitoid, relatif aman bagi manusia. Mimba merupakan salah satu pestisida namati yang digunakan secara meluas diberbagai belahan dunia(Shivkumara, 2019). Bahkan bagi 34 manusia daun mimba sering dijadikan bahan obatan. Daun mimba mengandung senyawasenyawa diantaranya adalah $\beta$-sitosterol, hyperoside, nimbolide, quercetin, quercitrin, rutin, azadirachtin, dan nimbine. Beberapa diantaranya diungkapkan memiliki aktivitas antikanker. Daun mimba mengandung nimbin, nimbine, 6-desacetylbimbine, nimbolide dan quercetin (Paul, 2011).

\section{Aplikasi Insektisida menggunakan Bantalan Kasa}

Sebagaimana dinyatakan oleh Marwoto (2016), pengendalian kumbang bubuk dapat dilakukan dengan insektisida dan fumigasi. Akan tetapi, insektisida hanya mungkin dilakukan untuk biji yang akan dijadikan benih, karena efek residunya akan terdegradasi dan hilang dalam proses pertumbuhan tanaman. Akan tetapi, untuk biji-bijian yang merupakan bahan pangan, hal ini tidak mungkin dilakukan karena residu akan menyebabkan keracunan bagi konsumen. Fumigasi adalah tindakan yang paling sesuai. Fumigasi yaitu melepaskan gas beracun ke suatu kawasan tertutup untuk menghilangkan semua bentuk kehidupan dari kawasan yang diaplikasikan. Tindakan ini lazim dilakukan pada bahan simpan untuk skala besar seperti penyimpanan oleh BULOG di Indonesia. Tetapi hal ini sangat tidak feasible untuk dilakukan dikalangan umum, karena fasilitas yang tidak mendukung dan potensi bahaya (hazard) yang dapat terjadi. Untuk itu, aplikasi pestisida nabati dengan bahan lokal yang mudah diperoleh menjadi alternatif yang paling feasible yang dapat dilakukan. Namun cara aplikasi yang harus dilakukan haruslah dipilih sedemikian rupa sehingga efisien disamping efektif. Cara aplikasi mencampurkan tepung daun mimba ke beras sebagaimana pengujian yang dilakukan oleh Rustam dkk (2017), tentu tidak aplikatif di lapangan, karena akan menimbulkan tampilan beras atau komoditas bahan simpan menjadi tidak menarik, walaupun bahan yang digunakan bersifat aman bagi manusia.

Untuk mengendalikan hama simpan, metoda aplikasi insektisida botani berbahan dasar daun sirih hutan dan daun mimba dapat dilakukan dengan metoda bantalan kasa. Pada metoda ini, daun kering sirih hutan dan mimba dapat dikamas di dalam bantalan yang terbuat dari bahan berpori halus (kasa), sehingga senyawa semiokimia aktif dapat keluar dan 
efektif melindungi bahan simpan dari hama namun tidak menimbulkan tampilan yang menurunkan kualitas bahan simpan. Cara aplikasi bantalan kasa dari sirih hutan dan daun mimba yang dapat menekan hama kumbang bubuk pada kacang tanah, sangat feasible untuk dilakukan baik oleh pedagang maupun tingkat konsumen rumah tangga.

\section{KESIMPULAN DAN SARAN}

\section{Kesimpulan}

Dari review literatur yang dilakukan, disimpulkan beberapa hal berikut:

1. Daun mimba dan daun sirih hutan sangat berpotensi untuk mengendalikan hama kumbang bubuk pada kacang tanah pada penyimpanan.

2. Aplikasi bahan insektisida nabati dengan metoda bantalan kasa merupakan cara yang sesuai menjaga bahan simpan dari serangan serangga hama disamping menjaga kualitas tampilan dari bahan yang dilindungi.

3. Metoda bantalan kasa merupakan cara mengaplikasikan pestisida nabati yang sesuai untuk dilakukan ditingkat pedagang baik pedagang besar bahkan hingga pedagang kecil.

\section{Saran}

Mengingat kandungan senyawa metabolit sekunder pada tanaman dapat bervariasi berdasarkan faktor internal dan eksternal dari suatu tumbuhan, perlu dilakukan kajian lanjut untuk standarisasi bahan untuk mendapatkan dosis yang efektif.

\section{DAFTAR PUSTAKA}

Anonimus. 2017. Manfaat dan Khasiat Sirih Hutan. Online pada: URL https://tanaman-herbal.blogspot.com/2017/03/manfaatdan-khasiat-tanaman-sirih-hutan.html. Diakses Tanggal 27 November 2019

Aradilla, A. S. 2009. Uji Efektivitas Larvasida Ekstrak Ethanol Daun Mimba (Azadirachta indica) terhadap Larva Aedes Aegypti. Skripsi (Tidak Dipublikasikan). Universitas Diponegoro, Semarang.

Arinda.2017. Insektisida Nabati sebagai Pilihan Pengendalian Hama Serangga. Online pada: URL http://farming.id/insektisidanabati-sebagai-pilihan-pengendalian- hama- serangga/. Diakses Tanggal 26 September 2020.

Arroyo-Acevedo, J., R. J. Chávez-Asmat, A . Anampa-Guzmán, R. Donaires, J. RáezGonzáles. 2015. Protective Effect of Piper Aduncum Capsule on DMBAInduced Breast Cancer in Rats. Breast Cancer (Auckl), 9: 41-48.

Laxmishree, C dan N. Singh. 2018. Review of Mode of action of some major botanical pesticides. Int. Res. Journal of Science \& Engineering, 6 (2): 129-132.

Marwoto. 2015. Hama Utama Kacang Tanah dan Strategi Pengendaliannya. Online pada:

http://balitkabi.litbang.pertanian.go.id/wp

content/uploads/2015/06/14._OK_Mwt_ Alfi_WIN_251-270-1.pdf. Diakses Tanggal 26 September 2020.

Morandim, A. D .A., M. J. Kato, A. J. Cavalheiro, M. Furlan. 2009. Intraspecific Variability of Dihydrochalcone, Chromenes and Benzoic Acid Derivatives in Leaves of Piper aduncum L. (Piperaceae). Afr J Biotechnol, 8:2157-2162.

Paul, R., M. Prasad. and N.K. Sah. 2011. Anticancer Biology of Azadirachta indica L (neem) A Mini Review. Cancer Biology \& Therapy, 12(6): 467-476.

Pires, E. M., E. Q. Souza, R. M. Nogueira, M. A. Soares, T. K. R. Dias, dan M. A. Oliveira. 2017. Damage Caused by Tribolium castaneum (Coleoptera: Tenebrionidae) in Stored Brazil nut. Scientific Electronic Archives. Online pada: Article link http://www.seasinop.com.br/revista/inde $\mathrm{x}$. php?journal $=$ SEA\&page $=$ article \&o $\mathrm{p}=$ view \& path $\% 5 \mathrm{~B} \% 5 \mathrm{D}=418 \&$ path $\% 5 \mathrm{~B}$ $\% 5 \mathrm{D}=$ pdf. Diakses Tanggal 29 September 2020.

Rustam, R., A. Sutikno, dan D. H. P. Putra. 2017. Pengaruh Beberapa Dosis Tepung Daun Sirih Hutan (Piper aduncum L.) terhadap Hama Kumbang Beras (Sitophilus oryzae L.). Jurnal Agrotek. Tropika, 6 (1): 17-22.

Saenong, M. S. 2016. Tumbuhan Indonesia Potensial sebagai Insektisida Nabati untuk Mengendalikan Hama Kumbang Bubuk Jagung (Sitophilus spp.). Jurnal Penelitian Pertanian Tanaman Pangan, 
35(3): 131-142.

Schmutterer, H. 1995. The Neem Tree Azadirachta indica A. Juss and Other Meliaceous Plants : Sources Of Uniques Natural Produts Fori Integrated Pest Management, Medicine, Industry, and Other Purpose. VCH, New York; Basel; Weinham; Cambridge; Tokyo. 35(2): 110.

Shivkumara, K. T., G. N. Manjesh, R. Satyajit and P. Manivel. 2019. Botanical Insecticides; Prospects and Way Forward in India: A review. Journal of Entomology and Zoology Studies, 7(3): 206-211.

Laxmishree, C dan N. Singh. 2018. Review of Mode of Action of Some Major Botanical Pesticides. Int. Res. Journal of Science \& Engineering, 6 (2): 129-132.

Wibawa, I. P. A. H. 2019. Uji Efektivitas Ekstrak Mimba (Azadirachta indica A. Juss.) untuk Mengendalikan Hama Penggerek Daun pada Tanaman Podocarpus neriifolius. E-Jurnal Agroekoteknologi, 8(1): 20-31.. 